\title{
Transient GUS gene expression in cassava (Manihot esculenta Crantz) using Agrobacterium tumefaciens leaf infiltration
}

\author{
Expresión transitoria del gen GUS en yuca (Manihot esculenta \\ Crantz) utilizando infiltración con Agrobacterium tumefaciens
}

Paula Díaz T, ${ }^{1}$ M.Sc, Adriana Bernal G, ${ }^{2}$ Ph.D, Camilo López C, ${ }^{1 *}$ Ph.D.

\begin{abstract}
${ }^{1}$ Universidad Nacional de Colombia, Science Faculty, Biology Department, Manihot Biotec Investigation Group, Calle 30 N 45-03, Bogota, Colombia. ${ }^{2}$ Universidad de los Andes, Science Faculty, Biology Department, LAMFU, Cra 1 N 18A- 12, Bogota, Colombia. *Correspondence: celopezc@unal.edu.co
\end{abstract}

Received: November 2013; Accepted: March 2014.

\begin{abstract}
Objective. Assess transient gene expression of GUS in cassava (Manihot esculenta Crantz) leaves using Agrobacterium tumefaciens infiltration. Materials and methods. A. tumefaciens strains GV3101 and AGL1 containing pCAMBIA1305.2 were used to evaluate transient gene expression of $\beta$-glucuronidase (GUS). A. tumefaciens infiltration (agroinfiltration) was made using both leaves from in vitro and 1 month old greenhouse plants. Leaves were incubated in X-GLUC buffer, stained and photographed to detect GUS activity. Results. Agroinfiltration assays showed GUS transient expression in leaves of cassava varieties widely cultivated in the north coast and eastern savannah, MCOL2215 (Venezuelan) and CM6438-14 (Vergara), respectively. A. tumefaciens agressive strain AGL1 showed high efficiency inducing GUS expression in cassava leaves. Conclusions. We recommend using $A$. tumefaciens agressive strain AGL1 for agroinfiltration to assess transient expression in cassava leaves.
\end{abstract}

Key words: Cassava, transient gene expression, Agrobacterium tumefaciens, beta-glucuronidase (Source: NAL USDA).

\section{RESUMEN}

Objetivo. Evaluar la expresión transitoria del gen GUS en hojas de yuca (Manihot esculenta Crantz) por medio de infiltración con Agrobacterium tumefaciens. Materiales y métodos. Se utilizaron las cepas GV3101 y AGL1 de $A$. tumefaciens conteniendo el plásmido pCAMBIA1305.2, para evaluar la expresión transitoria del gen GUS. La infiltración de $A$. tumefaciens (agroinfiltración) se realizó tanto en hojas de plantas "in Vitro" como de plantas adultas de 1 mes. Las hojas se incubaron en tampón X-GLUC, se destiñeron y se fotografiaron para detectar la actividad de la enzima $\beta$-glucuronidasa (GUS). Resultados. Los ensayos de agroinfiltración en hoja muestraron la expresión transitoria del gen GUS en variedades cultivadas en la costa norte y en los llanos orientales, MCOL2215 (Venezolana) y CM6438-14 (Vergara) respectivamente, 
tanto en plantas "in Vitro" como en plantas adultas. La cepa hipervirulenta de A. tumefaciens AGL1 mostró una mayor eficiencia para la expresión transitoria en hojas de yuca. Conclusiones. Se recomienda utilizar la cepa AGL1 para evaluar la expresión transitoria de genes de interés por agroinfiltración en hojas de yuca.

Palabras clave: Agrobacterium tumefaciens, beta-glucuronidasa, expresión transitoria, yuca (Fuente: NAL USDA).

\section{INTRODUCTION}

Cassava (Manihot esculenta Crantz) is a perennial shrub of the Amazon (1). It was initially domesticated in the southern Amazon basin, and in the XVI century was taken to East Africa by Portuguese sailors (1). In spite of it's Amazonic origin, it is currently cultivated in more than 100 countries, principally in low-land tropical regions, with an estimated production of $\mathbf{2 4 0}$ million tons a year in 2009 (2). Cassava is considered one of the main sources of food and energy in many countries around the world and is the third source of calories in the tropics, after rice and corn (3).

The most important part of the plant for food production is the root (4). The high starch concentration (20-40\% $\mathrm{p} / \mathrm{p}$ ) makes this crop the focus of interest as an energy source not just for human consumption but also for its industrial applications, such as bioethanol (3.5), which is currently obtained from a diversity crops including cassava.

Cassava crop is highly resistant to agroecological conditions adverse for many crops, this is mainly due to it's tolerance to drought and acidic soils (6). Additionally, a high content of cyanogenic glycosides makes it highly tolerant to generalist herbivores. All these characteristics, as well as the cassava's response to high concentrations of $\mathrm{CO}_{2}$, make this crop potentially highly resilient to global climate changes (2).

However, cassava production is compromised due to various diseases and pests that are produced by virus, fungus, bacteria and insects (4). There are currently no resistance genes to any of the diseases affecting this crop, and therefore it is important to study the molecular mechanisms (especially resistant genes) that explain immunity of the resistance varieties in order to introduce them, by means of conventional or biotechnological breeding strategies, into the susceptible cultivated varieties.

Recent advances in the development of new technologies in the area of molecular biology have produced a drastic reduction in the sequencing costs of complete genomes (7). Since the release of the Arabidopsis genome in the year 2000 (8) complete genome sequences of many plant species have been made available to the public. The complete

\section{INTRODUCCIÓN}

La yuca (Manihot esculenta Crantz) es un arbusto perenne de origen amazónico (1). Fue domesticada inicialmente en el Sur de la cuenca amazónica y en el siglo XVI fue llevada al Este de África por navegantes portugueses (1). A pesar de su origen amazónico, actualmente es cultivada en más de 100 países, principalmente en tierras bajas del trópico, con una producción estimada en 240 millones de toneladas por año para el 2009 (2). La yuca es considerada como una de las principales fuentes de alimento y energía para muchos países en el mundo y ocupa el tercer puesto como fuente de calorías en el trópico después del arroz y el maíz (3).

El órgano más importante para la producción son las raíces almacenadoras (4). Su alto contenido de almidón (20-40\% p/p)), convierte a este cultivo en un foco de interés para su utilización como fuente de energía no sólo por el consumo humano, sino también por sus aplicaciones industriales dentro de las que se destaca actualmente la obtención de bioetanol $(3,5)$.

El cultivo de yuca es resistente a condiciones agroecológicas adversas para muchos cultivos, debido a su tolerancia al estrés hídrico y suelo ácidos (6). Adicionalmente, su alto contenido de glicósidos cianogénicos lo hace altamente tolerante a herbívoros generalistas. Todas estas características junto con la respuesta de la yuca a altas concentraciones de $\mathrm{CO}_{2}$, lo convierten en un cultivo con un alto potencial de resistencia frente al cambio climático global (2).

Sin embargo, la producción de este cultivo está comprometida por causa de varias enfermedades y pestes, producidas por virus, hongos, bacterias e insectos (4). Actualmente no existen genes de resistencia a ninguna de las enfermedades de este cultivo, es por esto que cobra importancia el estudio de los mecanismos moleculares (especialmente genes de resistencia) que explican la inmunidad en las variedades resistentes para introducirlos mediante estrategias de mejoramiento convencional o biotecnológico a las variedades susceptibles cultivadas. 
genome sequence of cassava is currently available, which contains around 30,000 genes that codify for proteins and almost 3,500 alternative transcripts (9). The availability of this information creates a need to develop simple and efficient strategies that allow functional validation of genes.

Usually, stable genetic transformation assays have been used to express or silence genes in order to evaluate their function $(10,11)$. However, for the majority of plants these approximations take time and are costly, even more so for a tetraploid species with high heterozygosity and a long lifecycle, such as cassava (5). Additionally, characterizing genes using the generation of transgenic plants requires using several lines due to differences in the levels of expression between individuals and the localization of the transgene in the genome (12).

Transient expression mediated by Agrobacterium tumefaciens emerged as an alternative and quick approximation for gene characterization (13). This approximation, as well as stable transformation, is based on the use of the tumorogenic bacteria A. tumefaciens (14), which has been previously transformed with a plasmid that contains the gene of interest. Studies of the gene that codify for the $\beta$-glucuronidase enzyme (GUS) have shown that when plants are stably transformed with the gene, healthy and fertile plants are produced. The $\beta$-glucuronidase enzyme from Escherichia coli, incubated with a colorless or non-fluorescent substrate, is capable of transforming it so that it is easily visible. The commonly used substrate is $\mathrm{X}$-gluc (5-bromo-4-chloro-3-indolyl glucuronide). This, together with the fact that the protein is highly stable in the cytoplasm of vegetable cells, makes it into an excellent reporter on gene expression in plants (15).

This approximation has been widely exploited in species such as Nicotiana benthamiana, N. tabacum and Arabidopsis thaliana, the first of these being a model for the study of transient expression due to easy leaf infiltration and high levels of expression over 48 hours. Additionally, this technique has been adopted in other species of agronomic and commercial interest such as beans, lettuce, pepper, and flax $(10,16)$.

Transient expression in leaves by infiltration of Agrobacterium tumefaciens (also known as agroinfiltration) is routinely used in several areas of investigation in molecular biology, not only to express external genes or gene silencing (11) but also to evaluate possible promoter sequences and to detect protein interactions (13). In the field of molecular plant-microbe interactions this approximation is especially used to characterize resistance genes $(13,16,17)$. In cassava, in spite of
Recientes avances en el desarrollo de nuevas tecnologías en el área de la biología molecular ha generado una drástica disminución en los costos de secuenciación de genomas completos (7). Desde la liberación del genoma de Arabidopsis en el año 2000 (8), se ha hecho disponible al público las secuencias de genomas completos de muchas especies vegetales. Actualmente se encuentra disponible la secuencia del genoma completo de yuca, el cual contiene alrededor de 30.000 genes que codifican para proteínas y casi 3.500 transcritos alternativos (9). La disponibilidad de esta información hace necesario el desarrollo de estrategias simples y eficientes que permitan la validación funcional de genes.

Usualmente, ensayos de transformación genética estable han sido empleados para sobre-expresar o silenciar genes, con la finalidad de evaluar la funcion de los mismos $(10,11)$. Sin embargo, para la mayoría de plantas estas aproximaciones consumen tiempo y son costosas, más aún para una especie tetraploide, con alta heterocigocidad y con un largo ciclo de vida, como la yuca (5). Adicionalmente, la caracterización de genes utilizando la generación de plantas transgénicas requiere la utilización de varias líneas debido a las diferencias en los niveles la expresión entre individuos y a la localización del transgen en el genoma (12).

La expresión transitoria mediada por Agrobacterium tumefaciens ha surgido como una aproximación alternativa y rápida para la caracterización génica (13). Esta aproximación, al igual que para transformación estable, se basa en el uso de la bacteria tumorogénica $A$. tumefaciens (14), la cual ha sido previamente transformada con un plásmido que contiene el gen de interés. Estudios del gen que codifica para la enzima $\beta$-glucuronidasa (GUS) han mostrado que cuando plantas son transformadas establemente con el gen, éstas producen individuos saludables y fértiles. La enzima $\beta$-glucuronidasa proveniente de Escherichia coli cuando se incuba con un sustrato incoloro o no fluorescente es capaz de transformarlo para que sea visible facilmente. El sustrato mas empleado es el X-gluc (5-bromo4-chloro-3-indolyl glucuronido). Esto, junto con el hecho de que la proteína es altamente estable en el citoplasma de la célula vegetal, convierte a este gen en un excelente reportero de la expresión de genes en plantas (15).

Esta aproximación ha sido ampliamente explotada en especies como Nicotiana benthamiana, N. tabacum y Arabidopsis thaliana, siendo la primera de éstas un modelo para el estudio de expresión transitoria debido a la facilidad de infiltración de las hojas y a los altos niveles de 
the importance of transient gene expression, there are few reports on the use of this approximation, and none of them by means of leaf agroinfiltration.

The objective of this study was to transiently express GUS gene from Escherichia coli in cassava leaves by infiltration with Agrobacterium tumefaciens in order to generate a quick methodological approximation for the functional analysis of cassava genes.

\section{MATERIALS AND METHODS}

Agrobacterium tumefaciens strains. Electrocompetent cells of GV3101 and AGL1 strains of $A$. tumefaciens were prepared. Bacteria were grown in a YEPA medium (yeast extract $10 \mathrm{~g} / \mathrm{L}$, peptone $10 \mathrm{~g} / \mathrm{L}$, glucose $20 \mathrm{~g} / \mathrm{L}$, agar-agar $15 \mathrm{~g} / \mathrm{L}$ ), with their respective antibiotics (Table 1 ). A colony was taken to inoculate $2 \mathrm{~mL}$ of YEP medium (yeast extract $10 \mathrm{~g} / \mathrm{L}$, peptone $10 \mathrm{~g} / \mathrm{L}$, glucose $20 \mathrm{~g} / \mathrm{L}$ ). From this preculture $400 \mu \mathrm{L}$ were taken and 300 $\mathrm{mL}$ were inoculated in YEP medium and incubated at $28^{\circ} \mathrm{C}$ to $250 \mathrm{rpm}$ in darkness until the culture reached $\mathrm{DO}_{600 \mathrm{~nm}}=0.75-0.95$. Washing steps were done using sterile $10 \%$ glycerol and bacteria were centrifuged at $3000 \mathrm{~g}$ during $10 \mathrm{~min}$ at $4^{\circ} \mathrm{C}$. Bacteria was resuspended in sterile $1 \mathrm{M}$ sorbitol and stored at $-80^{\circ} \mathrm{C}$.

The strains were transformed by electroporation with pCambia1305.2 plasmid (Canberra, Australia), which contains the GUSPlus gene in the T-DNA interrupted by a catalase intron with the objective of evaluating the gene expression produced by the plant. The selection was performed in LB medium (tryptone $10 \mathrm{~g} / \mathrm{L}$, yeast extract $5 \mathrm{~g} / \mathrm{L}$, Sodium chloride $5 \mathrm{~g} / \mathrm{L}$ ), agar $15 \mathrm{~g} / \mathrm{L}$ using antibiotics for each strain and kanamycin $(50 \mu \mathrm{g} / \mathrm{mL})$ for the plasmid selection. The colonies were picked and the presence of the GUSPlus gene was directly evaluated using PCR (Polymerase Chain Reaction). All PCR reactions were done in a final volume of 10 $\mu \mathrm{L}: 1 \mathrm{x}$ of DreamTaqTM Buffer (ThermoScientific, Waltham, MA, USA), $0.2 \mu \mathrm{M}$ of GUSPlusFw primer ( $5^{\prime}$-CTC TTG CCA TCC TTG TCC TC-3'), $0.2 \mu \mathrm{M}$ of GUSPlusRv primer ( $5^{\prime}$-AGC CGA AAT CTG GAA TGT TG-3'), $0.1 \mathrm{mM}$ dNTPs (each), $0.25 \mathrm{U}$ of DreamTaqTM DNA polymerase (ThermoScientific, Waltham, MA, USA). An initial denaturation at $95^{\circ} \mathrm{C}$ was done for $5 \mathrm{~min}$, followed by 35 cycles of amplification (denaturation at $95^{\circ} \mathrm{C}$ for $30 \mathrm{sec}$,

Table 1. Strains of $A$. tumefaciens used in this study.

\begin{tabular}{ccc}
\hline Strain & Gene marker & Plasmid Ti \\
\hline GV3101 & Rif & pMP90 (pTiC58DT-DNA) \\
AGL1 & Carb & pEHA105 (pTiB0542DT-DNA) \\
\hline
\end{tabular}

\footnotetext{
The antibiotic rifampicin $(100 \mu \mathrm{g} / \mathrm{mL})$ was used as gene marker of
} the chromosome for GV3101, and Carbenicillin $(100 \mu \mathrm{g} / \mathrm{mL})$ for AGL1. expresión después de 48 horas. Adicionalmente, esta técnica ha sido adoptada en otras especies de interés agronómico y comercial como fríjol, tomate, lechuga, pimentón y lino $(10,16)$.

La expresión transitoria en hojas por la infiltración de Agrobacterium tumefaciens (también llamada agroinfiltración) se emplea rutinariamente en varias áreas de investigación en biología molecular, no sólo para la expresión de genes externos o silenciamiento génico (11) sino también para la evaluación de posibles secuencias promotoras y para detectar interacciones proteicas (13). En el campo de la fitopatología molecular, esta aproximación se usa especialmente para la caracterización de genes de resistencia $(13,16$, 17). En yuca, a pesar de la importancia de la expresión transitoria de genes, existen pocos reportes del uso de esta aproximación, ninguno de ellos por medio de agroinfiltración en hojas.

Es por eso que en este trabajo se evaluó la expresión transitoria del gen GUS proveniente de Escherichia coli en hojas de yuca por medio de infiltración con Agrobacterium tumefaciens, con el fin de generar una aproximación metodológica rápida para el análisis funcional de genes en yuca.

\section{MATERIALES Y MÉTODOS}

Cepas de Agrobacterium tumefaciens. Se prepararon células electrocompetentes de las cepas GV3101 y AGL1 de A. tumefaciens. Para esto se crecieron las bacterias en medio YEPA (extracto de levadura $10 \mathrm{~g} / \mathrm{L}$, peptona $10 \mathrm{~g} / \mathrm{L}$, glucosa $20 \mathrm{~g} / \mathrm{L}$, agar-agar $15 \mathrm{~g} / \mathrm{L}$ ), con sus respectivos antibióticos (Tabla 1 ). Se tomó una colonia y se realizó un precultivo en $2 \mathrm{~mL}$ de medio YEP (extracto de levadura $10 \mathrm{~g} / \mathrm{L}$, peptona $10 \mathrm{~g} / \mathrm{L}$, glucosa $20 \mathrm{~g} / \mathrm{L})$. De este precultivo se tomaron $400 \mu \mathrm{L}$ y se inocularon $300 \mathrm{~mL}$ de medio YEP y se incubó a $28^{\circ} \mathrm{C}$ a 250 RPM en oscuridad hasta que el cultivó alcanzó una $\mathrm{DO}_{600 \mathrm{~nm}}=0.75$ - 0.95. Los lavados se realizaron utilizando glicerol estéril al $10 \%(\mathrm{v} / \mathrm{v})$ y las bacterias se centrifugaron a $3000 \mathrm{~g}$ durante $10 \mathrm{~min}$ a $4^{\circ} \mathrm{C}$. Las bacterias se resuspendieron en sorbitol $1 \mathrm{M}$ estéril y se almacenaron $\mathrm{a}-80^{\circ} \mathrm{C}$.

Las cepas fueron electroporadas con el plásmido pCambia1305.2 (Canberra, Australia), el cual contiene el gen GUSPlus en el T-DNA interrumpido por un intrón de catalasa, con el objeto de evaluar la expresión del gen producido por la planta. La selección se realizó en medio LB (triptona 10 $\mathrm{g} / \mathrm{L}$, extracto de levadura $5 \mathrm{~g} / \mathrm{L}$, cloruro de sodio $5 \mathrm{~g} / \mathrm{L}$, agar $15 \mathrm{~g} / \mathrm{L}$ ) utilizando los antibióticos para cada cepa y kanamicina $(50 \mu \mathrm{g} / \mathrm{mL})$ para la 
annealing at $53^{\circ} \mathrm{C}$ for $30 \mathrm{sec}$, extension at $72^{\circ} \mathrm{C}$ for $2 \mathrm{~min}$ ), a final extension at $72^{\circ} \mathrm{C}$ for $10 \mathrm{~min}$ and a final incubation at $20^{\circ} \mathrm{C}$ for $10 \mathrm{~min}$. In each case a sample without DNA was included as a negative control and pCAMBIA1305.2 plasmid DNA as a positive control.

Vegetal material and growth conditions. In vitro plants and one month old plants propagated from woody cuttings were used. The woody cuttings were obtained from stems of adult plants from La Vega, Cundinamarca, Colombia. All plants were grown in a greenhouse on the property of the Universidad Nacional de Colombia in Bogotá. The greenhouse temperature varied between 28 and $35^{\circ} \mathrm{C}$ during the day and between 22 and $27^{\circ} \mathrm{C}$ at night. Humidity was kept at $70 \%$ and a $12 \mathrm{~h}$ light/ $12 \mathrm{~h}$ darkness photoperiod was maintained. The plants were kept in trays with water to provide a continuous supply of moisture.

The in vitro plants were obtained from a germplasm collection at the Centro Internacional de Agricultura Tropical (CIAT), under a material transfer agreement (MTA). They were transferred to soil and kept in the greenhouse under the previously mentioned conditions for adult plants.

The 60444, CM6438-14 and MCOL2215 varieties were used. The 60444 variety has proved to be more efficient in genetic transformation in cassava (18) and is used as a model in transformation studies $(19,20)$. The MCOL2215 and CM643814 varieties are commercial ones that are widely cultivated on the Caribbean coast and the plains (Los Llanos) of Colombia (21).

Leaf agroinfiltration. An isolated colony was taken from a fresh culture for each one of the strains used (GV3101 and AGL1). It was inoculated using LB with the respective antibiotics and it was incubated at $28^{\circ} \mathrm{C}$ at $250 \mathrm{rpm}$ in darkness until it reached $\mathrm{DO}_{600 \mathrm{~nm}}$ $=0.8-1.0$. The culture centrifuged at $3000 \mathrm{rpm}$ for $10 \mathrm{~min}$, the supernatant was removed and it was washed using an infiltration solution of $0.5 \mathrm{X}$ (MES $5 \mathrm{mM}, \mathrm{MgCl}_{2} 5 \mathrm{mM}$, acetosyringone $75 \mu \mathrm{M}$, $\mathrm{pH}$ 5.6). The culture was again centrifuged and was resuspended in an agroinfiltration solution $1 \mathrm{X}$ (MES $10 \mathrm{mM}, \mathrm{MgCl}_{2} 10 \mathrm{mM}$, acetosyringone 150 $\mu \mathrm{M}, \mathrm{pH}$ 5.6). For each culture $\mathrm{DO}_{600 \mathrm{~nm}}=0.3$ and 0.03 (depending on the experiment) was adjusted and it incubated at room temperature $\left(20^{\circ} \mathrm{C}\right)$ for 4 hours (13).

For agroinfiltration assays young, green leaves were selected. The leaves were kept on the plant during and after agroinfiltration, and were removed just before staining to visualize the $\beta$-glucuronidase (GUS) enzyme activity. Before infiltration a small puncture was performed with a needle close to selección del plásmido. Se realizó un repique de las colonias y se evaluó directamente la presencia del gen GUSPlus mediante PCR (Polymerase Chain Reaction). Todas las reacciones de PCR se realizaron en un volumen final de $10 \mu \mathrm{L}$ : $1 x$ de DreamTaq ${ }^{\mathrm{TM}}$ Tampón (ThermoScientific, Waltham, MA, USA), $0.2 \mu \mathrm{M}$ de primer GUSPlusFw (5 ' -CTC TTG CCA TCC TTG TCC TC-3 ') , $0.2 \mu \mathrm{M}$ de primer GUSPlusRv (5'-AGC CGA AAT CTG GAA TGT TG-3'), 0.1 mM dNTPs (cada uno), $0.25 \mathrm{U}$ de DreamTaq ${ }^{\mathrm{TM}}$ DNA polymerase (ThermoScientific, Waltham, MA, USA). Se realizó una denaturación inicial a $95^{\circ} \mathrm{C}$ durante $5 \mathrm{~min}$, seguido de 35 ciclos de amplificación (denaturación a $95^{\circ} \mathrm{C}$ durante $30 \mathrm{seg}$, anillamiento a $53^{\circ} \mathrm{C}$ durante $30 \mathrm{seg}$, extensión a $72^{\circ} \mathrm{C}$ durante $2 \mathrm{~min}$ ), una extensión final a $72^{\circ} \mathrm{C}$ durante $10 \mathrm{~min}$ y una incubación final a $20^{\circ} \mathrm{C}$ durante $10 \mathrm{~min}$. En todos los casos se incluyó como control negativo una muestra sin ADN y como control positivo el ADN plasmídico de pCAMBIA1305.2.

Material vegetal y condiciones de crecimiento. Se utilizaron plantas "in Vitro" y plantas de 1 mes propagadas a partir estacas leñosas. Las estacas leñosas fueron obtenidas a partir de tallos de plantas adultas crecidas en La Vega, Cundinamarca. Todos los cultivares fueron crecidos en un invernadero en las instalaciones de la Universidad Nacional de Colombia, sede Bogotá. La temperatura del invernadero durante el día osciló entre $28-35^{\circ} \mathrm{C}$ y durante la noche entre $22-27^{\circ} \mathrm{C}$. La humedad se mantuvo alrededor de $70 \%$ y se mantuvo un fotoperíodo de 12 h luz/ 12h oscuridad. Las plantas se mantuvieron sobre bandejas con agua para permitir la continua disponibilidad de humedad.

Las plantas "in Vitro" fueron obtenidas de la colección de germoplasma del Centro Internacional de Agricultura Tropical (CIAT), previo un acuerdo de transferencia de material (ATM). Se transfirieron a suelo y se mantuvieron en el invernadero bajo las condiciones mencionadas anteriormente para las plantas adultas.

Se emplearon las variedades 60444, CM643814 y MCOL2215. La variedad 60444 es la que ha presentado mayores eficiencias en transformación genética en yuca (18) y se emplea como modelo en estudios de transformación (19, 20). Las variedades MCOL2215 y CM6438-14 son variedades comerciales ampliamente cultivadas en la Costa Caribe y en los Llanos de Colombiana (21).

Agroinfiltración de la hoja. Se tomó una colonia aislada de un cultivo fresco para cada una de las cepas empleadas (GV3101 y AGL1). Se inoculó medio LB con los respectivos antibióticos 
the central nerve on the underside of the leaf. The infiltration was performed using a $1 \mathrm{~mL}$ syringe without a needle, allowing the solution to enter through the opening made with the needle (13).

Infiltrations were done at room temperature $\left(20^{\circ} \mathrm{C}\right)$ and the plants were kept in these conditions until the GUS staining was performed.

GUS staining. After three days of post-infiltration (DPI) the leaves were separated from the plant and submerged in $50 \mathrm{~mL}$ polypropylene tubes with a X-Gluc buffer $\left(\mathrm{NaH}_{2} \mathrm{PO}_{4} 0.02 \mathrm{M}, \mathrm{Na}_{2} \mathrm{HPO}_{4} 0.03\right.$ $\mathrm{M}, \mathrm{K}_{3} \mathrm{FeCN}_{6} 0.25 \mathrm{mM} \mathrm{K}_{4} \mathrm{FeCN}_{6} 0.25 \mathrm{mM}$, triton X-100 $0.5 \%(\mathrm{v} / \mathrm{v})$, DMSO $10 \%(\mathrm{p} / \mathrm{v})$ and X-Gluc (5-bromo-4-chloro-3-indolyl $\beta$-D-glucuronide) 1 $\mathrm{mg} / \mathrm{mL}$ (Sigma, St. Louis, MO, USA). In the last assays the tubes were placed in an empty chamber during 15-30 min (depending on the test) at a pressure of $20 \mathrm{mmHg}$ and were incubated at $37^{\circ} \mathrm{C}$ for $16 \mathrm{~h}$ without agitation (22). In vitro cassava plants that constitutively express the GUSPlus gene were used as a positive control (22), and plants infiltrated with the infiltration solution as a negative control.

\section{RESULTS}

Use of the GV3101 strain for agroinfiltration assays in cassava plants. As a preliminary assay it was decided to evaluate in first instance transient expression only in the GV3101 strain, widely used in transient expression assays in Nicotiana benthamiana $(10,13,23)$. For this, $A$. tumefaciens GV3101::pMP90 was transformed with the pCAMBIA1305.2 plasmid for evaluation of cassava. This strain was infiltrated in cassava leaves of the MCOL2215 and 60444 varieties, and after 3 DPI the activity of the GUS enzyme was determined by means of staining with an X-gluc buffer. As seen in Table 2, no expression of the GUSPlus gene in either of the two varieties was observed. No coloring in the in vitro plants was observed, or in the adult plants obtained from cuttings (Table 2). However, an intense blue coloring was observed in transgenic plants that express the GUSPlus gene constitutively under the CP2 promoter (22), which were used as a positive control in the GUS staining. All of these experiments were repeated twice with similar results.

Transient expression of the GUSPIus gene in the leaves of in vitro cassava plants using the aggressive $A$. tumefaciens AGL1 strain. Although the GV3101 strain is frequently used in transient expression assays in a wide variety of vegetal species, the hypervirulent AGL1 strain was evaluated, which is used for the stable transformation of friable embryogenic callus (FEC) y se incubó a $28^{\circ} \mathrm{C}$ a $250 \mathrm{rpm}$ en oscuridad hasta que alcanzó una $\mathrm{DO}_{600 \mathrm{~nm}}=0.8-1.0 \mathrm{El}$ cultivo se centrifugó a $3000 \mathrm{rpm}$ durante $10 \mathrm{~min}$, se descartó el sobrenadante y se realizó un lavado utilizando solución de infiltración $0.5 X$ (MES 5 $\mathrm{mM}, \mathrm{MgCl}_{2} 5 \mathrm{mM}$, acetosiringona $75 \mu \mathrm{M}, \mathrm{pH}$ 5.6). Se centrifugó nuevamente el cultivo y se resuspendió en solución de agroinfiltración $1 \mathrm{X}$ (MES $10 \mathrm{mM}, \mathrm{MgCl}_{2} 10 \mathrm{mM}$, acetosiringona 150 $\mu \mathrm{M}, \mathrm{pH}$ 5.6). Para cada cultivo se ajustó la $\mathrm{DO}_{600 \mathrm{~nm}}$ $=0.3$ y 0.03 (dependiendo del experimento) y se incubó a temperatura ambiente durante 4 horas (13).

Para los ensayos de agroinfiltración se seleccionaron hojas jóvenes y verdes. Las hojas se mantuvieron en la planta durante y después de la agroinfiltración, se eliminaron justo antes de realizar la tinción para visualizar la actividad de la enzima $\beta$-glucuronidasa (GUS). Previo a la infiltración se realizó una pequeña punción con una aguja cerca al nervio central por el envés de la hoja. La infiltración se realizó usando una jeringa de $1 \mathrm{~mL}$ sin aguja permitiendo la entrada de la solución por la abertura realizada con la aguja (13).

Las infiltraciones se realizaron a temperatura ambiente $\left(20^{\circ} \mathrm{C}\right)$ y las plantas se mantuvieron en estas condiciones hasta la realización de la tinción GUS.

Tinción GUS. Después de 3 días post-infiltración (DPI) se separaron las hojas de la planta y se sumergieron en tubos de polipropileno de $50 \mathrm{~mL}$ con tampón X-Gluc $\left(\mathrm{NaH}_{2} \mathrm{PO}_{4} 0.02 \mathrm{M}\right.$, $\mathrm{Na}_{2} \mathrm{HPO}_{4} 0.03 \mathrm{M}, \mathrm{K}_{3} \mathrm{FeCN}_{6} 0.25 \mathrm{mM}_{4}, \mathrm{~K}_{4} \mathrm{FeCN}_{6}$ $0.25 \mathrm{mM}$, tritón $\mathrm{X}-1000.5 \%(\mathrm{v} / \mathrm{v})$, DMSO 10 $\%(p / v)$ y X-Gluc (5-bromo-4-cloro-3-indolil $\beta$-D-glucuronido) $1 \mathrm{mg} / \mathrm{mL}$ (Sigma, St. Louis, MO, USA). En los últimos ensayos se colocaron los tubos en una cámara de vacío durante 15 y 30 min (dependiendo del ensayo) a una presión de $20 \mathrm{mmHg}$ y se incubaron a $37^{\circ} \mathrm{C}$ durante 16 h sin agitación (tomado de (22)). Como control positivo se emplearon plantas de yuca "in Vitro" que expresan constitutivamente el gen GUSPlus (22) y como control negativo plantas infiltradas con la solución de infiltración.

\section{RESULTADOS}

Uso de la cepa GV3101 para ensayos de agronfiltración en hojas de yuca. Como ensayo preliminar se decidió evaluar en primera instancia la expresión transitoria solamente con la cepa GV3101, ampliamente utilizada en ensayos de expresión transitoria en Nicotiana benthamiana $(10,13,23)$. Para esto, se 
Table 2. Transient expression assay of the GUSPlus gene in cassava leaves using GV3101 strain of Agrobacterium tumefaciens containing the pCAMBIA1305.2 plasmid.

\begin{tabular}{cccc}
\hline Genotype & Material & DO $_{\text {600nm }}$ & GUS strain \\
\hline 60444 & in Vitro & 0.03 & - \\
60444 & in Vitro & 0.3 & - \\
60444 & Greenhouse & 0.03 & - \\
60444 & Greenhouse & 0.3 & - \\
MCOL2215 & in Vitro & 0.03 & - \\
MCOL2215 & in Vitro & 0.3 & - \\
MCOL2215 & Greenhouse & 0.03 & - \\
MCOL2215 & Greenhouse & 0.3 & - \\
$60444($ Cp2::GUSPlus) & in Vitro & NA & + \\
\hline
\end{tabular}

${ }^{a}$ Transgenic plants that express the GUSPlus gene under the CP2 promoter (22). NA, not applicable.

in cassava (22). To do this, in virtro plant leaves of the MCOL2215 variety were infiltrated with the AGL1 strain containing the pCAMBIA1305.2 plasmid, and after 3 DPI the activity of the GUS enzyme was determined by X-Gluc staining. In figure 1 blue-stained regions are observed at the infiltration site, which indicates biochemical activity of the GUS enzyme and therefore a transient expression of the GUSPlus gene. Additionally, the intensity of the stained region is directly related to the OD of the bacteria culture used in the infiltration (Figure 1). This same assay was done in in vitro plant leaves of the 60444 variety with similar results (data not shown). However, in spite of having used

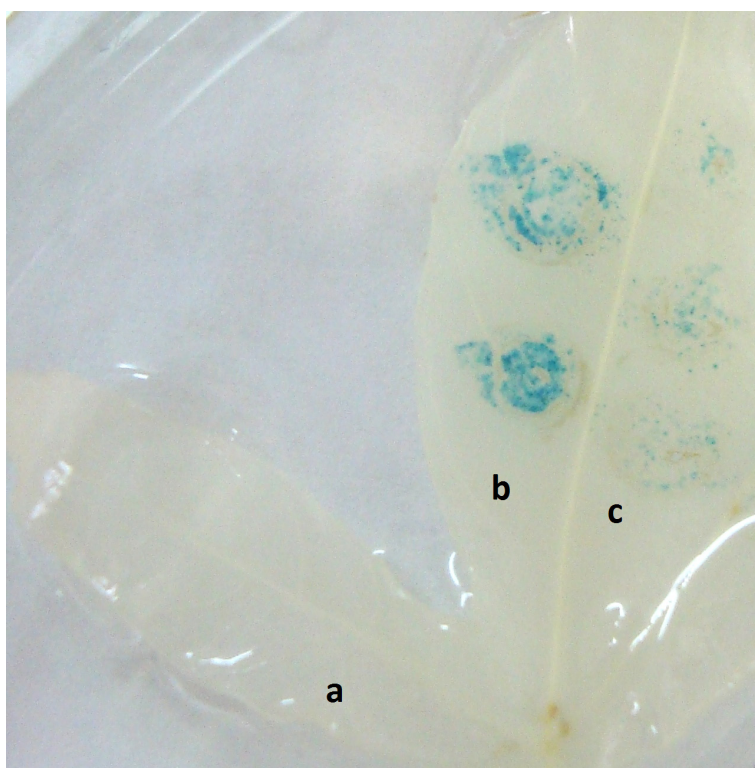

Figure 1. Transient expression of the GUS gene in in vitro cassava leaves (MCOL2215 variety) using the AGL1 strain containing pCAMBIA1305.2 plasmid. Infiltration of the solution without $A$. tumefaciens (negative control) (a), infiltration of the AGL1 strain containing pCAMBIA1305.2 plasmid to a $\mathrm{DO}_{600}=0.03$ (b) $\circ \mathrm{DO}_{600}=0.003$ (c). transformó A. tumefaciens GV3101: :pMP90 con el plásmido pCAMBIA1305.2 para la evaluación en yuca. Se infiltró esta cepa en hojas de yuca de las variedades MCOL2215 y 60444, y después de 3 DPI se determinó la actividad de la enzima GUS mediante la tinción con el tampón X-gluc. Como se observa en la tabla 2, no se observó expresión del gen GUSPlus en ninguna de las dos variedades empleadas. Tampoco se observó ninguna coloración en plantas "in Vitro" ni en plantas adultas obtenidas a partir de estacas (Tabla 2). Sin embargo, sí se observó coloración azul intensa en las plantas transgénicas que expresan el gen GUSPlus constitutivamente bajo el promotor CP2 (22), las cuales fueron empleadas como control positivo de la tinción GUS. Todos estos experimentos se repitieron dos veces con resultados similares.

\section{Expresión transitoria del gen GUSPlus en} hojas de yuca de plantas in Vitro usando la cepa agresiva de $A$. tumefaciens AGL1. Aunque la cepa GV3101 es frecuentemente empleada en ensayos de expresión transitoria en una amplia gama de especies vegetales, se decidió evaluar la cepa hipervirulenta AGL1, la cual es utilizada para la transformación estable de callo embriogénico friable (CEF) en yuca (22). Para esto, se infiltraron hojas de plantas "in Vitro" de la variedad MCOL2215, con la cepa AGL1 conteniendo el plásmido pCAMBIA1305.2, y después de 3 DPI se determinó la actividad de la enzima GUS mediante la tinción con X-Gluc. En la figura 1 se observan regiones que presentan una coloración azul en el sitio de la infiltración, lo que indica actividad bioquímica de la enzima GUS y por lo tanto expresión transitoria del gen GUSPlus. Adicionalmente, se observa que la intensidad de la coloración está directamente relacionada con la DO del cultivo bacteriano empleado en la infiltración (Figura 1). Este mismo ensayo se realizó en hojas de plantas "in Vitro" de la variedad 60444 obteniéndose resultados similares (datos no mostrados). Sin embargo, a pesar de haber empleado las mismas condiciones de infiltración con Agrobacterium, en plantas adultas obtenidas a partir de estacas no se obtuvo coloración azul para ninguna de las dos variedades de yuca empleadas (datos no mostrados).

Infiltración del tampón X-gluc con vacío en hojas de estacas. Mientras que las hojas de yuca de las plantas "in Vitro" son delgadas y de consistencia membranosa, las hojas de yuca de plantas provenientes de estacas presentan un mayor grosor y una consistencia ligeramente coriácea, además de la producción de exudado de látex blanco. Estas características de las hojas de plantas provenientes de estacas generan una 
the same infiltration conditions with Agrobacterium, blue staining was not obtained in adult plants from cuttings for either of the two varieties of cassava used (data not shown).

Infiltration of the $X$-gluc buffer in vacuum in leaves from cuttings. While cassava leaves from in vitro plants are thin and membranous, cassava leaves from plants from cuttings are thicker and have a slightly leathery consistency, and produce a white latex exudate. These characteristics of the leaves of plants from cuttings generate greater resistance to liquid penetration to the tissues. The X-Gluc buffer's inaccessibility in the infiltrated tissue could explain the negative results in detecting GUS enzyme activity when performing the infiltration of leaves from cuttings. In order to efficiently detect GUS enzyme activity, the vacuum effect on the $X$-Gluc buffer entering the infiltrated tissue was evaluated. The leaves of adult plants were subject to a vacuum chamber for 15 min with the purpose of promoting the entrance of the X-Gluc buffer into
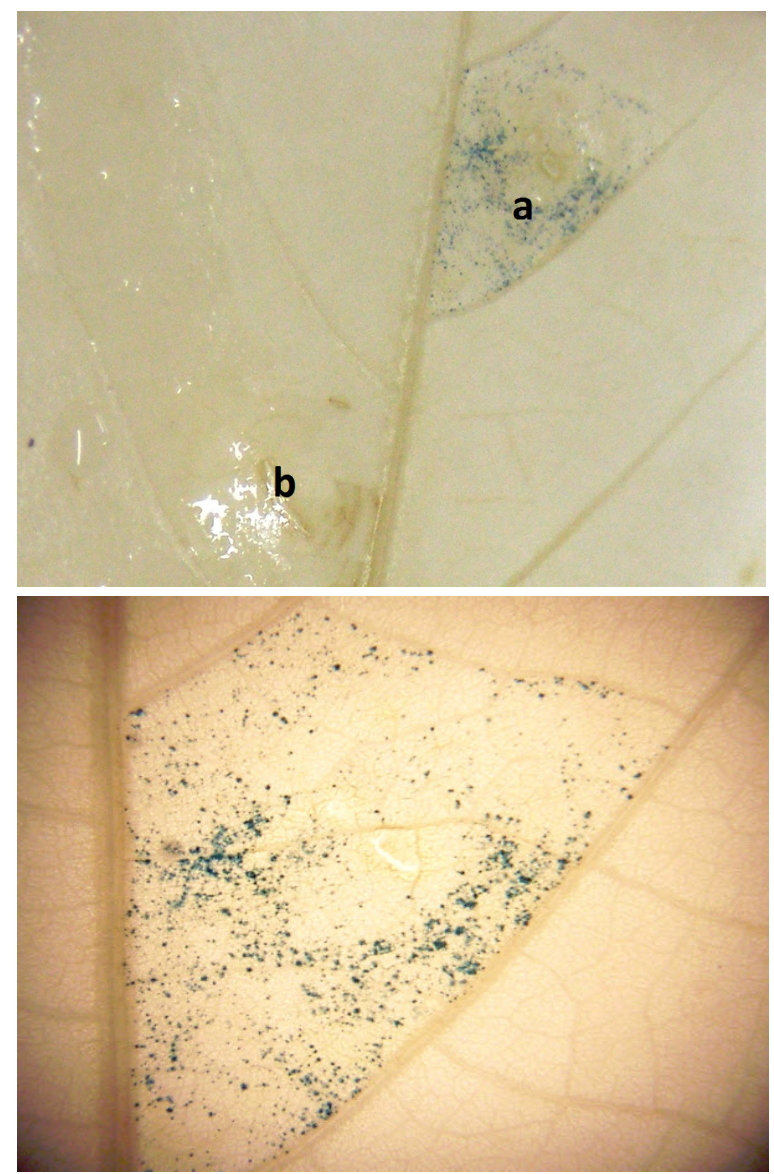

Figure 2. Transient expression of the GUS gene by leaf agroinfiltration of an adult plant of the CM6438-14 variety. The AGL1 strain containing pCAMBIA1305.2 plasmid at $\mathrm{DO}_{600}=0.03$ (a) was infiltrated, agroinfiltration solution was used as a negative control (b). The image below shows an increase in the a region. mayor resistencia a la entrada de líquidos a los tejidos. La inaccesibilidad del tampón X-Gluc al tejido infiltrado, podría explicar los resultados negativos en la detección de la actividad de la enzima GUS al realizar la infiltración en hojas de estacas. Con miras a detectar eficientemente la actividad de la enzima GUS, se evaluó el efecto del vacío sobre la entrada del tampón $\mathrm{X}$-Gluc al tejido infiltrado. Las hojas de plantas adultas fueron sometidas a una cámara de vacío durante 15 min con el fin de promover la entrada del tampón X-Gluc al tejido. En la figura 2 se puede observar la región infiltrada ocupada de puntos azules, lo cual demuestra la actividad bioquímica de la enzima GUS y por lo tanto la expresión transitoria del gen GUSPlus en hojas provenientes de plantas de estaca de la variedad comercial CM6438-14.

Con el propósito de obtener mayores niveles de expresión transitoria en hojas adultas provenientes de plantas de estaca, se aumentó la incubación en la cámara de vacío a 30 minutos con una presión de $-20 \mathrm{mmHg}$. En la figura 3 se observa una coloración azul intensa que abarca toda la región infiltrada, correspondiente a la expresión transitoria del gen GUSPlus en hojas de plantas de estaca de la variedad comercial CM6438-14.

\section{DISCUSIÓN}

La expresión transitoria mediante infiltración en hojas mediante Agrobacterium tumefaciens es una herramienta ampliamente utilizada en diversos campos dentro de la biología molecular de plantas $(10,11,13-17)$.

En yuca, se ha logrado estandarizar protocolos de transformación genética estable usando callo embriogénico friable (CEF) a partir del cultivar modelo cv. 60444 (18-20). Esto ha permitido la introducción de características de interés agronómico, la cuales por mejoramiento genético tradicional podrían haber tomado mucho más tiempo. Considerando el largo ciclo de vida de la yuca se ha establecido que la generación de variedades mejoradas puede tardar entre 4 a 7 años $(4,18,20)$. Sin embargo, en yuca el proceso desde la producción de CEF hasta la obtención de plantas transgénicas puede tardar entre 1216 meses $(18,19)$. Por lo tanto, la posibilidad de evaluar de forma rápida y eficiente genes candidatos a ser transformados establemente, mediante expresión transitoria en hojas de yuca, podría constituirse una herramienta útil previa a la transformación genética estable. Esto ayudaría a disminuir costos y tiempo en la transformación estable de genes que puedan 
the tissue. In figure 2 the infiltrated region has blue spots, which demonstrates the biochemical activity of the GUS enzyme and therefore the transient expression of the GUSPlus gene in leaves from cuttings of the CM6438-14 commercial variety.

In order to obtain greater levels of transient expression in adult leaves from cuttings, incubation in the vacuum chamber was increased to 30 minutes with $-20 \mathrm{mmHg}$ pressure. In figure 3 an intense blue stained region was observed taking up the whole infiltrated region, corresponding to the transient expression of the GUSPlus gene in leaves of cuttings from the CM6438-14 commercial variety.

\section{DISCUSSION}

Transient expression by means of Agrobacterium tumefaciens leaf infiltration is a widely used tool in several fields of plant molecular biology $(10,11$, 13-17).

In cassava, protocols of stable genetic transformation have been standardized using friable embryogenic callus (FEC) from model cultivar cv. 60444 (18-20). This has allowed the introduction of characteristics of agronomic interest, which by traditional breeding may have taken much longer. Considering the long lifecycle of cassava, it has been established that generation of improved varieties can take between 4 to 7 years $(4,18,20)$. However, in cassava production process from FEC to the generation of transgenic plants can take between 12 to 16 months $(18,19)$. Therefore, the possibility of quickly and efficiently evaluating gene candidates to be stably transformed by means of transient expression in cassava leaves could become a useful tool previous to stable genetic transformation. This will help diminish costs and time in the stable transformation of genes that can cause adverse effects in the plants. For example, the introduction of toxicity genes will not allow plants to be regenerated. Also, the introduction of resistance genes whose constitutive expression would cause cellular death (one of the principal plant response mechanisms to pathogens) will not allow plant regeneration. On the contrary, transient expression of putative $\mathrm{R}$ genes in leaves followed by later inoculation with a pathogen will allow a quick validation of their role in resistance.

In this study, transient expression of the GUSPlus gene was evaluated in cassava leaves by $A$. tumefaciens infiltration. Although activity of the GUSPlus gene was not detected in leaves of the MCOL2215 variety and Cv. 60444 when using the GV3101 strain, the possibility that this strain could also be able to promote transient expression in cassava is not dismissed, though with less efficiency

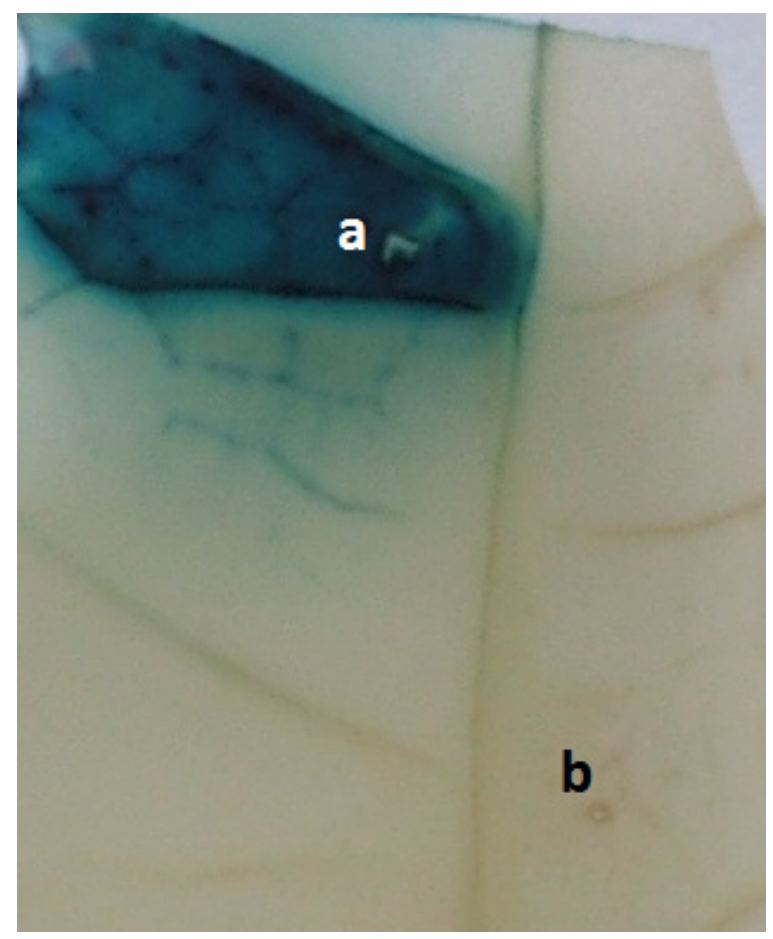

Figure 3. Transient expression of the GUSPlus gene by means of leaf agroinfiltration from a plant cutting of the commercial variety CM6438-14. The AGL1 strain containing pCAMBIA1305.2 plasmid at D0600 $=0.3$ (a) was infiltrated, agroinfiltration solution was used as a negative control (b).

causar efectos adversos en la planta. Por ejemplo la introducción de genes de toxicidad no permitiría regenerar plantas. Así también la introducción de genes de resistencia cuya expresión constitutiva provocaría una muerte celular (uno de los principales mecanismos de respuestas de las plantas a los patógenos) tampoco permitiría la regeneración de plantas. Por el contrario la expresión transitoria de genes R putativos, seguido de la posterior inoculación con un patógeno permitiría una rápida validación de su función en resistencia.

En este trabajo se evaluó la expresión transitoria del gen GUSPlus en hojas de yuca por infiltración de $A$. tumefaciens. Aunque no se detectó actividad del gen GUSPlus en hojas de la variedad MCOL2215 y cv. 60444 al emplear la cepa GV3101, no se descarta la posibilidad de que esta cepa también pueda ser capaz de promover la expresión transitoria en yuca, pero con menor eficiencia comparada con la cepa hipervirulenta AGL1. Se ha encontrado que la eficiencia de la expresión transitoria por agroinfiltración es altamente dependiente de la cepa de $A$. tumefaciens y del genotipo de la planta $(10,13)$. Es posible que genotipos 
compared to the hypervirulent AGL1 strain. It has been found that the efficiency of transient expression by agroinfiltration is highly dependent on the strain of $A$. tumefaciens and the genotype of the plant $(10,13)$. It is possible that particular genotypes (varieties) of plants are capable of specifically recognizing certain types of strains and cause resistance; avoiding the introduction of T-DNA of $A$. tumefaciens, which would be reflected in low efficiencies in the transient expression genes of reporter genes or of interest. Preliminary data in our investigation group showed that in cassava greater levels of expression of the GUSPlus gene are obtained when the AGL1 strain is used, compared with LBA4404 and GV3101 strains (data not published). This could suggest that varieties of cassava are more sensitive to this type of strain.

These results additionally show consistency and structure of the leaves dependence for the detection of transient expression of the GUSPIus gene. In vitro plants leaves are thinner with a membranous consistency, rendering them adequate for agroinfiltration assays in cassava. On the other hand, plants from cuttings have thicker leaves with a slightly leathery consistency, which combined with the production of a latex exudate, restrict the entrance of aqueous solutions to the interior of the leaf. However, as observed in figures 2 and 3, this limitation is overcome by the use of the vacuum chamber which decreases pressure temporarily. The above, followed by the re-establisement of atmospheric pressure leads to the entrance of the solution to the interior of the tissue. Optimization in assays of transient expression by $A$. tumefaciens diminishing pressure by using vacuum chambers has already been previously reported for several plant species $(10,24)$.

In summary, these results suggest the use of the hypervirulent AGL1 strain and in vitro plants to perform transient expression assays by means of agroinfiltration in cassava leaves.

\section{Acknowledgments}

Paul Chavarriaga and members of the Manihot Biotec investigation group for scientific advice in the development of assays and the enriching discussions. To the Universidad Nacional de Colombia, Vicerrectoría Académica, PDT is beneficiary of the BESP scholarship.

\section{Conflict of interest}

The authors declare that there is no conflict of interest particulares (variedades) de plantas sean capaces de reconocer de manera específica cierto tipo de cepas y desencadenen una resistencia; evitando de esta manera la introducción del T-ADN de $A$. tumefaciens, lo cual se reflejaría en bajas eficiencias en la expresión transitoria de los genes reporteros o de interés. Datos preliminares en nuestro grupo de investigación muestran que en yuca, se obtienen mayores niveles de expresión del gen GUSPlus cuando se emplea la cepa AGL1, comparados con la utilización de las cepas LBA4404 y GV3101 (datos no publicados). Esto podría sugerir que las variedades de yuca son más sensibles a este tipo de cepa.

Los resultados demuestran adicionalmente una dependencia de la consistencia y estructura de las hojas en la detección de expresión transitoria del gen GUSPlus. Las plantas in Vitro al presentar hojas con una consistencia membranosa y un menor grosor, son más adecuadas para los ensayos de agroinfiltración en yuca. Por otro lado, las plantas de estacas presentan hojas más gruesas y con una consistencia ligeramente coriácea, lo cual junto con la producción de un exudado de látex, restringe la entrada de soluciones acuosas al interior de las hojas. Sin embargo, como se observa en las figuras 2 y 3, esta limitación es superada por el uso de una cámara de vacío la cual genera una momentánea disminución de la presión. Lo anterior, seguido de la recuperación de la presión atmosférica es lo que permite la entrada de la solución al interior del tejido. La optimización en ensayos de expresión transitoria mediada por $A$. tumefaciens disminuyendo la presión mediante el uso de cámara de vacío ya ha sido reportada anteriormente para diversas especies vegetales $(10,24)$.

En síntesis estos resultados sugieren el uso de la cepa hipervirulenta AGL1 y plantas "in Vitro" para realizar ensayos expresión transitoria mediante agroinfiltración en hojas de yuca.

\section{Agradecimientos}

Paul Chavarriaga y miembros de grupo de investigación Manihot Biotec por la asesoría científica en el desarrollo de los ensayos y a las discusiones enriquecedoras. A la Universidad Nacional de Colombia, Vicerrectoría Académica, PDT es beneficiaria de la beca BESP.

\section{Conflicto de intereses}

Los autores declaran que no existe conflicto de intereses 


\section{REFERENCES}

1. Olsen KM, SNPS, SSRs and inferences on cassava's origin. Plant Mol Biol 2004; 56(4):517-26.

2. Taylor NJ, Fauquet CM, Tohme J. Overview of Cassava Special Issue. Tropical Plant Biol 2012; 5:1-3.

3. FAO. Cassava's huge potential as 21st Century crop. [en línea]. Roma: Organización de las Naciones Unidades para la Agricultura y la Alimentación. 2013. [consultado 30 Mayo 2013]. URL disponible en: http:// www.fao.org/news/story/en/item/176780/ icode/

4. Ceballos H, Okogbenin E, Pérez JC, López-Valle LAB, Debouck D. Cassava. In: Bradshaw JE, editor. Root and tuber crops. London: SpringerLink; 2010.

5. Balat $\mathrm{M}$, Balat $\mathrm{H}$. Recent trends in global production and utilization of bio-ethanol fuel. Applied Energy 2009; 86(11):2273-82.

6. El-Sharkawy MA. Cassava biology and physiology. Plant mol biol 2004; 56(4):481-501.

7. Von Bubnoff A. Next-Generation Sequencing: The Race Is On. Cell 2008; 132(5):721-3.

8. Yamada K, Lim J, Dale JM, Chen H, Shinn $P$, Palm CJ, et al. Empirical Analysis of Transcriptional Activity in the Arabidopsis Genome. Science 2003; 302(5646):842-846.

9. Prochnik $S$, Marri PR, Desany B, Rabinowicz PD, Kodira C, Mohiuddin M, et al. The Cassava Genome: Current Progress, Future Directions. Tropical Plant Biol 2012; 5:88-94.

10. Wroblewski T, Tomczak A, Michelmore R. Optimization of Agrobacterium-mediated transient assays of gene expression in lettuce, tomato and Arabidopsis. Plant Biotechnol J 2005; 3(2):259-73.

11. Voinnet O, Rivas S, Mestre P, Baulcombe D. An enhanced transient expression system in plants based on suppression of gene silencing by the $\mathrm{p} 19$ protein of tomato bushy stunt virus. Plant J 2003; 33:949-56.
12. Kohli A, Twyman RM, Abranches R, Wegel E, Stoger $E$, Christou P. Transgene integration, organization and interaction in plants. Plant Mol Biol 2003; 52(2):247-258.

13. Ma L, Lukasik E, Gawehns F, Takken FLW. The Use of Agroinfiltration for Transient Expression of Plant Resistance and Fungal Effector Proteins in Nicotiana benthamiana Leaves. Cap: Bolton MD, Thomma BPHJ, editors. Plant Fungal Pathogens: Methods and Protocols. Amsterdam: SpringerLink; 2012.

14. McCullen CA, Binns AN. Agrobacterium tumefaciens and Plant Cell Interactions and Activities Required for Interkingdom Macromolecular Transfer. Annu Rev Cell Dev Biol 2006; 22(1):101-27.

15. Lee M, Yang Y. Transient Expression Assay by Agroinfiltration of Leaves. In: Salinas J, SanchezSerrano JJ, editors. Arabidopsis protocols. New Jersey: Humana Press Inc; 2006.

16. Dodds PN, Lawrence GJ, Catanzariti AM, Teh T, Wang CI, Ayliffe MA, et al. Direct protein interaction underlies gene-forgene specificity and coevolution of the flax resistance genes and flax rust avirulence genes. Proc Natl Acad Sci USA 2006; 103(23):8888-93.

17. Leckie BM, Neal Stewart C. Agroinfiltration as a technique for rapid assays for evaluating candidate insect resistance transgenes in plants. Plant cell rep 2010; 30(3):325-34.

18. Taylor $N$, Chavarriaga $P$, Raemakers $K$, Siritunga D, Zhang P. Development and application of transgenic technologies in cassava. Plant mol biol 2004; 56(4):671-88.

19. Bull SE, Owiti JA, Niklaus M, Beeching JR, Gruissem W, Vanderschuren H. Agrobacterium-mediated transformation of friable embryogenic calli and regeneration of transgenic cassava. Nat Protoc 2009; $4(2): 1845-54$.

20. Sayre R, Beeching JR, Cahoon EB, Egesi C, Fauquet C, Fellman J, et al. The BioCassava Plus Program: Biofortification of Cassava for Sub-Saharan Africa. Annu Rev Plant Biol 2011; 62(1):251-72. 
21. Alzate A M, Vallejo F, Ceballos H, Pérez J C, Fregene M. Variabilidad genética de la yuca cultivada por pequeños agricultores de la región Caribe de Colombia. Acta agronómica 2010; 59(10):385-393.

22. Beltrán J, Prías M, Al-Babili S, Ladino $Y$, López D, Beyer $P$, et al. Expression pattern conferred by a glutamic acid-rich protein gene promoter in field-grown transgenic cassava (Manihot esculenta Crantz). Planta 2010; 231(6):1413-24.
23. Kim MJ, Baek K, Park C-M. Optimization of conditions for transient Agrobacteriummediated gene expression assays in Arabidopsis. Plant cell Rep 2009; 28(8): 1159-67.

24. Simmons CW, VanderGheynst JS, Upadhyaya SK. A model of Agrobacterium tumefaciens vacuum infiltration into harvested leaf tissue and subsequent in planta transgene transient expression. Biotechnol Bioeng 2009; 102(3):965-70. 